\title{
Price Undertakings in EU Anti-dumping Proceedings - an Instrument of the Past?
}

\author{
Armin Steinbach \\ German Ministry of Economics, Berlin, Germany
}

\begin{abstract}
Price undertakings are alternatives to imposing anti-dumping duties. In the past, almost half of EU anti-dumping measures were price undertakings. This has drastically changed in recent years. We identify four reasons for the decreasing relevance of price undertakings. First, prior to the accession of Eastern European Countries (EEC) to the EU, price undertakings were heavily used vis-à-vis EEC. At the same time, China became frequent subject of anti-dumping proceedings, where undertakings were rarely used due to monitoring issues. Second, unlike anti-dumping duties, price undertakings are often difficult to monitor and can be circumvented more easily. Third, there are reasons related to the suitability of price undertakings to remove dumping practice and injurious effects, particularly in the context of high price volatility. Fourth, price undertakings may have potentially anti-competitive effects, as minimum prices tend to exacerbate competition policies.
\end{abstract}

JEL Classifications: F13, F14, F51, F55

Key words: International Trade, Anti-dumping, Price Undertakings, Competition

\footnotetext{
* Corresponding Author: Armin Steinbach; German Ministry of Economics, Scharnhorststrasse 11, 10117 Berlin, Germany; German; Tel: +49 15120660846, E-mail: armin.steinbach@gmail.com. 


\section{Introduction}

The Commission of the European Union (EU) has two alternative options at hand to conclude an anti-dumping proceeding: first, the Commission can impose anti-dumping duties or, second, it can accept price undertakings offered by the exporting companies. ${ }^{1}$ A price undertaking is an agreement between the Commission and the exporter whereby the latter agrees to raise the price to the extent that the Commission is satisfied that either the dumping margin or the injurious effects thereof are eliminated. ${ }^{2}$

Whereas duties tend to punish the dumping exporters by levying a tax on their exports, price undertakings are perceived to have a more amicable character compared to duties, since they allow the exporting firms to raise their prices and ceteris paribus collect higher profits on exported production. ${ }^{3}$ There are contradictory interests involved when price undertakings are at stake. Usually, exporting companies prefer a price undertaking over an ad valorem-duty because the additional income resulting from the price increase accrues to them, whereas anti-dumping duties accrue to the Community. ${ }^{4}$ By contrast, the complaining industry is typically opposed to price undertakings, mainly because the price increasing effect of the undertaking typically tends to remain below those of anti-dumping duties.

In the past, the Commission frequently used price undertakings as an instrument to settle anti-dumping proceedings. Until 2001, around $40 \%$ of EU anti-dumping proceedings were settled by way of implementing price undertakings. However, in recent years a sharp decline has occurred in implementing price undertakings, as the EU Commission made relatively more use of anti-dumping duties. This raises the question of whether and to what extent price undertakings still have a role to play in future anti-dumping proceedings. Against this background, the aim of this contribution is to identify the reasons for decreasing use of price undertakings in settling anti-dumping cases. In particular, the practice of the EU Commission ought to be examined regarding price undertakings.

\footnotetext{
${ }^{1}$ Van Bael and Bellis (2011), p. 399ff.

${ }^{2}$ See Article 10 of Council Regulation 384/96 of December 22, 1995 on protection against dumped imports from countries not members of the European Community ("the Basic Anti-Dumping Regulation"), OJ 1996 L 56/1, as last amended by Regulation (EC) No 2117/2005 of December 21, 2005; for an economic analysis of price undertakings see Moore (2005); Perone (1995).

${ }^{3}$ Everaert (2003), p. 6. Although this depends on the import elasticity of the exported good.

${ }^{4}$ Van Bael and Bellis (2011), p. 433.

${ }^{5}$ Zanardi (2004).
} 
Therefore, the first part provides an empirical evaluation of the use of price undertakings and lays out the legal requirements setting. From a political economy perspective, the divergent interests of the various stakeholders involved in anti-dumping proceedings are considered.

On the empirical evidence of the declining relevance of price undertakings, the second part discusses the grounds for the EU Commission to reject price undertakings. One reason is related to the importance of the recent accession of the EEC to the EU and the infrequent use of price undertakings vis-à-vis China. The analysis then identifies two categories of grounds for rejection. First, monitoring effectiveness of price undertakings and limiting the risk of circumvention. Second, the suitability of price undertakings to remove the dumping practice and the injurious effects thereof.

The third part discusses a further category of reasons for rejecting price undertakings, i.e., competition policy. The analysis identifies the market conditions under which a price undertaking is likely to produce anti-competitive effects.

The contribution of this article is three-fold. First, despite the importance of antidumping procedures as an instrument of EU economic policy vis-à-vis third countries, until now no comprehensive examination of the use of price undertakings in EU anti-dumping proceedings has been provided. We fill this gap. Second, this analysis complements the empirical record of price undertakings in the decisional practice of the EU and highlights the changing role that price undertakings have been playing in the recent years. Third, on the basis of the decisional practice of the EU Commission, this analysis provides an explanatory framework for the comparative disadvantages of price undertakings compared to anti-dumping duties.

The analysis concludes that one reason for the declining relevance of price undertakings in anti-dumping proceedings lies in the shift of countries being subject to anti-dumping proceedings. A further reason is related to the comparative disadvantages of price undertakings vis-à-vis the ad-valorem anti-dumping duties. The latter have clear advantages in effectively administering and monitoring that dumping and its injurious effects are factually removed. Moreover, ad valorem-duties can avoid potential conflicts with the competition goals of the EU, which might occur where price undertakings are implemented in certain market structures. The strong opposition of Community industry against the regular use of price undertakings may reinforce the Commission's inclination to prefer anti-dumping duties. On balance, the scope of price undertakings is likely to remain rather limited in settling anti-dumping cases. 


\section{The Relevance of Price Undertakings}

This section explains the relevance of price undertakings and identifies the substantive and procedural requirements governing price undertakings imposed by the relevant legal norms.

\section{A. Empirical Evaluation of Price Undertakings in the EU}

The role of price undertakings in the Commission's practice as instrument to settle anti-dumping proceedings has changed over time. During some periods, price undertakings were used nearly as often as traditional ad valorem-duties. During the last ten years, however, the frequency of price undertakings has declined and has fallen sharply since 2010 .

Previous studies have provided only anecdotal empirical evaluation of the use of price undertakings. Messerlin (1989) found that in the period between 1980 and 1985 around $40 \%$ of all anti-dumping cases ended in price undertakings. ${ }^{6}$ Of those, $6.9 \%$ were ended by the foreign firm agreeing to raise its price to eliminate the dumping margin. Far more frequently (33.2\%), the European Commission negotiated agreements under which the margin of "injury" was eliminated, which most often meant that foreign firms agreed not to undersell their European competitors.

Moore (2004) refers to the statistics from the European Commission, according to which 23 of the 161 anti-dumping orders in place by December 31, 1998 involved price undertakings. 'Of these, seven involved quantitative restrictions designed to "eliminate injury" including two cases involving non-WTO members. The remaining cases were resolved by taking minimum prices to eliminate injury.

The most comprehensive evaluation of the use of price undertakings was presented by Zanardi (2004). ${ }^{8}$ He shows that between 1981 and 2001 around 40 per cent of EU anti-dumping proceedings were settled by implementing price undertakings.

Table 1 illustrates the use of price undertakings over the eleven years following

\footnotetext{
${ }^{6}$ Messerlin (1989).

${ }^{7}$ European Commission (1998).

${ }^{8}$ Zanardi (2004), p. 425, Table 5; for a recent overall assessment of EU anti-dumping measures see Davis (2009).

${ }^{9}$ See also the analysis by Rovegno and Vandenbussche (2011), Figure 4.
} 
the period examined by Zanardi (2004). Between 2002 and 2005, price undertakings were still performed relatively often in relation to the overall number of anti-dumping measures imposed and oscillated around an average of $37 \%$. Since 2005, price undertakings have been used less frequently and have declined sharply in recent years. In 2011 and 2012, undertakings accounted for less than 10\% out of all anti-dumping settlements.

Table 1. Use of Price Undertakings to Settle Anti-dumping Proceedings in the EU

\begin{tabular}{c|c|c|c}
\hline & $\begin{array}{c}\text { Number of definitive anti- } \\
\text { dumping duties imposed }\end{array}$ & $\begin{array}{c}\text { Number of price undertakings } \\
\text { accepted by the EU Commission }\end{array}$ & $\begin{array}{c}\text { Percent of } \\
\text { undertakings }\end{array}$ \\
\hline 2012 & 2 & 0 & $0.00 \%$ \\
\hline 2011 & 11 & 1 & $8.33 \%$ \\
\hline 2010 & 6 & 1 & $14.29 \%$ \\
\hline 2009 & 9 & 1 & $10.00 \%$ \\
\hline 2008 & 16 & 4 & $20.00 \%$ \\
\hline 2007 & 12 & 1 & $7.69 \%$ \\
\hline 2006 & 13 & 3 & $18.75 \%$ \\
\hline 2005 & 19 & 8 & $29.63 \%$ \\
\hline 2004 & 3 & 2 & $52.63 \%$ \\
\hline 2003 & 25 & 12 & $40.00 \%$ \\
\hline 2002 & 125 & 43 & $32.43 \%$ \\
\hline $2002 \sim 2012$ & 343 & 235 & $21.25 \%$ \\
\hline $1981 \sim 2001$ & & & $40.66 \%$ \\
\hline
\end{tabular}

(Source) Own calculations based on Statistical Reports from the European Commission 1999 2012; Zanardi (2004); figures for 2012 are based on available statistics until August 2012.

In sum, the frequency of price undertakings has fallen by almost half from an average of more than $40 \%$ between 1981 and 2001 to $21 \%$ during the period from 2002 and 2012. The analysis will show that the recent decline can be assigned to a more restrictive practice regarding price undertakings by the EU Commission. 
Figure 1. Price Undertakings versus Duties

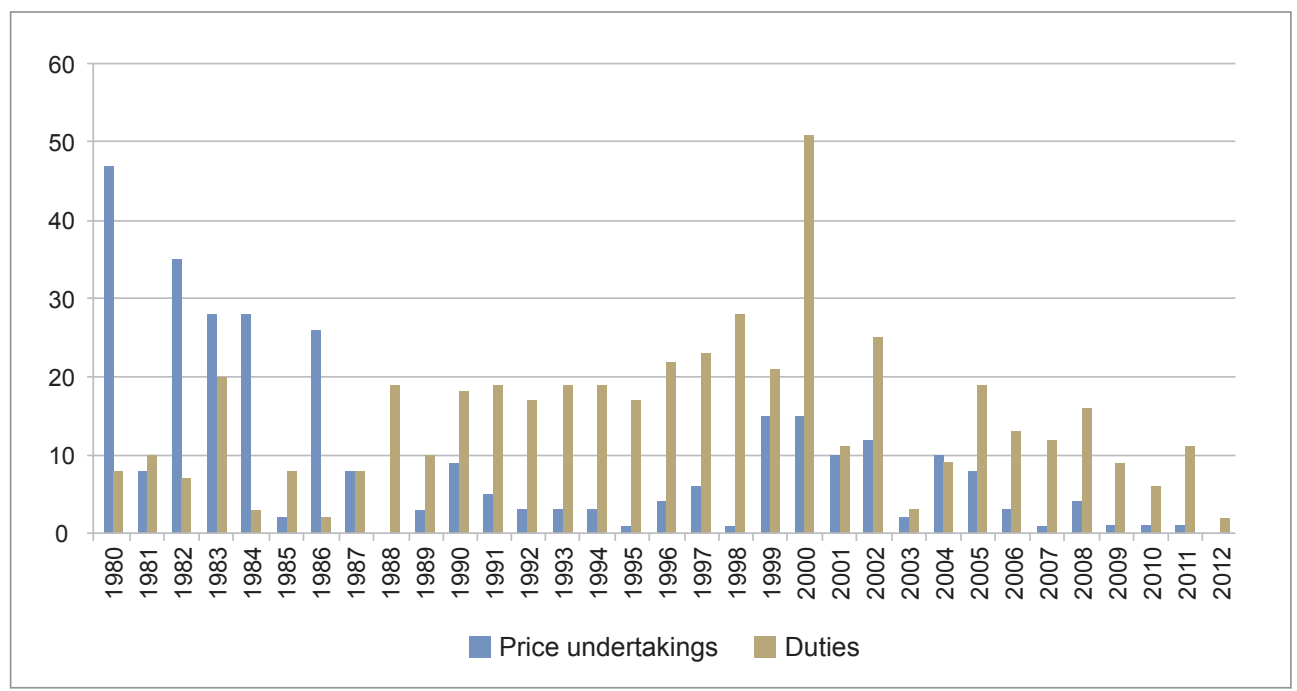

(Source) Statistical Reports from European Commission

Figure 1 provides a picture on how the use of price undertakings has varied over time. Until 1987, price undertakings were used extensively and significantly exceeded the use of anti-dumping duties. This changed sharply from 1990, when price undertakings were used more rarely until 1998. Between 1999 and 2005 price undertakings were then used more often again, while still less frequently than anti-dumping duties. As said above, from 2006 the number of price undertakings declined significantly.

\section{B. Rules governing Price Undertakings in Anti-dumping Proceedings}

The EU Commission's approach towards offers of price undertakings is determined by the legal framework governing price undertakings. The rules are laid down in two distinct legal sources: The EU Basic Anti-Dumping Regulation ${ }^{10}$ and the WTO Agreement ${ }^{11}$. The Basic Anti-Dumping Regulation contains the rules applicable to individual companies and lays down the procedure for anti-dumping proceedings. The

\footnotetext{
${ }^{10}$ Council Regulation 384/96 of December 22, 1995 on protection against dumped imports from countries not members of the European Community ("the Basic Anti-Dumping Regulation"), OJ 1996 L 56/1, as last amended by Regulation (EC) No 2117/2005 of December 21, 2005.

${ }^{11}$ Agreement on Implementation of Article VI of the General Agreement on Tariffs and Trade 1994 (Anti-Dumping Agreement).
} 
Basic Anti-Dumping Regulation is required to be in conformity with the WTO AntiDumping Agreement. Given the relevance of these two distinct bodies of law, the jurisprudence of both the European Court of Justice (ECJ) and WTO dispute settlement bodies have further substantiated the conditions for price undertakings.

The analytical basis for the Commission's evaluation of a price undertaking is provided in Article 8 of the Basic Anti-Dumping Regulation. According to its paragraph 1, the Commission "may accept satisfactory voluntary undertaking offer [...] if it is satisfied that the injurious effect of the dumping is thereby eliminated." Moreover, according to Article 8 (3) "undertakings offered need not be accepted if their acceptance is considered impractical, if such as where the number of actual or potential exporters is too great, or for other reasons, including reasons of general policy".

Given the broad conditions for the acceptance of price undertakings, the ECJ stated that "Article 14(1) of the basic regulation leaves the Community institutions a wide discretion to determine, in each case, the appropriate type of duty." ${ }^{12}$ Also, the WTO Panel on the US - Offset Act stated that investigating authorities do not need to accept price undertakings and that the reasons for rejections may be manifold. ${ }^{13}$ This language confirms that the Commission is under no obligation to accept undertakings and it may invoke reasons linked to practicability in rejecting undertakings.

Article 15 of the Anti-Dumping Agreement does not limit the Commission's discretion either. It provides that "special regard must be given by developed country Members to the special situation of developing country Members when considering the application of anti-dumping measures" and that "possibilities of constructive remedies provided for by this Agreement shall be explored before applying anti-dumping duties where they would affect the essential interests of developing country Members."

The special regard for developing countries has repeatedly been invoked in antidumping procedures by companies from developing countries in order to request the acceptance of price undertakings. Often the individual company's situation or performance has been put forward as a ground to request the acceptance of a price undertaking. However, in US - Steel Plate, the Panel concluded that special regard is to be given to the situation of developing country Members, and not to the situation

\footnotetext{
${ }^{12}$ See, e.g., Combined Cases C-189/88, Cartorobica Spa v Ministero delle Finanze dello Stato, [1990] ECR, I-1269, 25 and T-87/98, International Potash Company v Council, [2000] ECR, II-3179, 40.

${ }^{13}$ WTO Panel Report, US - Offset (Byrd Amendment), para. 7.81.
} 
of companies operating in developing countries. ${ }^{14}$ Thus, the importance of the relevant commodity for the developing country concerned (in terms of its share of total merchandise exports to the EU) has to be taken into account, irrespective of the situation of the individual company and the consequences that anti-dumping duties may have on that company.

The decision whether to accept the offer for a price undertaking must therefore be made in line with the relevant legal framework under Community law. In that respect, the Commission, while enjoying a wide margin of discretion, is bound to act in a consistent, non-discriminatory fashion. It is, therefore, submitted that the Commission considers an undertaking offer against the background of; (i) whether such an undertaking is an effective remedy; (ii) whether its acceptance is consistent with other general Community policies; (iii) whether the undertaking can be easily implemented in practice.

\section{Interests involved in the Acceptance of Price Undertakings}

Given the wide latitude the Commission enjoys when considering price undertakings, account should be taken from a political economy perspective of the controversial interests involved, which result from the different nature of price undertakings compared to anti-dumping duties. While duties tend to 'punish' the dumping exporters by levying a tax on their exports, price undertakings are perceived to have a more 'amicable' character, since they generally allow the exporting firms to raise their prices and ceteris paribus collect higher profits. ${ }^{15}$ Whether the company accepting price undertakings is ultimately better off depends, however, on the elasticity of demand facing the exporting firms. Consider the extreme and most simple case in which import demand is perfectly elastic (rendering the exporting firms "small"), the firms are thus price takers. Any attempt by such firms to undertake a price increase will reduce the quantity purchased from them to zero. Even if we are not considering the extreme case, in general there are many areas of the import demand curve whereby any attempt by the firms to increase price will lead them to having lower total revenue and lower profits.

The interests at stake in the negotiation of price undertakings differ significantly

\footnotetext{
${ }^{14}$ Panel Report on US - Steel Plate, para. 7.111. "Simply because a company is operating in a developing country does not mean that it somehow shares the "special situation" of the developing country Member.".

${ }^{15}$ Everaert (2003), p. 6.
} 
from those of anti-dumping measures. The exporting company usually has a genuine interest in the price undertaking over the ad valorem-duty, because the additional income resulting from the price increase accrues to them, whereas anti-dumping duties accrue to the Community. ${ }^{16}$ Another advantage for the exporter is the fact that undertakings can be terminated at short notice in the event of significant changes in the marketplace, whereas duties remain in force for at least five years unless a review procedure is successful. ${ }^{17}$ On the other hand, the exporter directly faces the consequences of a price increase, while in the case of anti-dumping duties exporters are left free to charge a lower price for their product provided that their importers pay the duty (irrespective of whether this complies with the anti-absorption rule).

Unlike the exporter, the complaining industry is typically opposed to price undertakings: first, because the price increasing effect from price undertakings tends to remain below anti-dumping duties and, second, because a price undertaking needs to be constantly monitored while in the case of duties the collection of the duty is automatic. ${ }^{18}$ Concerns about possible circumvention practices are the argument most referred to by Community industry to reject undertakings. By contrast, there are two advantages of price undertakings for the complaining industry, which may in some cases provide an argument to accept the undertaking. First, an undertaking offers more rapid relief than the imposition of anti-dumping duties. Second, in some cases price undertakings also include an arrangement on the quantities that are allowed to be imported, which provides further relief for the complaining EU industry.

Importers of the product concerned often align their positions with the exporting company. They are worse off no matter whether a price undertaking is implemented or anti-dumping duties are imposed. Thus, importers often put forward the acceptance of price undertakings when they expect the price mark-up to be below the size of the ad valorem-duty imposed. In particular, importers have an incentive to offer price undertakings in a scenario in which price increases are expected.

It remains speculative as to what extent divergent interests may effectively influence the Commission's discretionary decisions on price undertakings. Overall examination of dumping cases indicates that Community institutions have attempted to balance the interests of consumers against the interests of Community industry, the latter have

\footnotetext{
${ }^{16}$ Van Bael and Bellis (2011), p. 433; for an analysis of strategic incentives in anti-dumping measures see Prusa and Skeath (2002).

${ }^{17}$ Article 11 (2) of the Basic Anti-Dumping Regulation.

${ }^{18}$ Van Bael and Bellis (2011), p. 433.
} 
consistently prevailed. ${ }^{19}$ Whether this is true or not, it can certainly be argued that the wide discretion of the Commission might facilitate a preferential account for the interests of one interest group over the other.

\section{Implementation of Price Undertakings}

As described above, the use of price undertakings has varied significantly over time. Given the recent declining use of price undertakings and the wide discretion of the Commission, this section identifies the key reasons to refuse offers for price undertakings. The Commission has developed a comprehensive case-law. On that basis, the reasons to reject price undertakings can broadly be classified into two categories: the first category relates to the risk of circumvention and the problems of effective monitoring of price undertakings. Previous practice shows that multiple difficulties may occur in the implementation and monitoring of price undertakings, which underscores the relative effectiveness of the imposition of ad valorem-duties compared to price undertakings. The second category of rejections is related to the suitability of price undertakings in order to effectively remove the dumping practice and the injurious effects thereof.

\section{A. Eastern European Countries and China}

The pattern illustrated in Table 2 shows that the EU anti-dumping practice vis-àvis Eastern European Countries (EEC) has to be considered. In fact, before 1987 the majority of cases were concluded by price undertakings. Vandenbussche (1995) linked this observation with the fact that before 1987 the majority of cases were against Eastern Europe. Combining these two results gives the impression that the EU has a strong bias towards accepting undertakings with respect to Eastern European countries.

Between 1980 and 2002, anti-dumping proceedings against EEC were in most cases settled by price undertakings. During that period the rate of price undertakings with

\footnotetext{
${ }^{19}$ Mendes (1991), p.160.

${ }^{20}$ Pauwels/Springael (2002), 125; Vandenbussche (1995), 55.
} 
EEC oscillated between $75 \%$ and $95 \%$, while the average use of price undertakings varied between $24 \%$ and $71 \%$.

The high level of the use vis-à-vis EEC is not surprising in light of the explicit EU trade policy to give preference to price undertakings. In 1994, the EU Council decided to give preferential treatment to EEC and seek price undertakings as the preferred tool to conclude anti-dumping proceedings. ${ }^{21}$ In addition, this preferential treatment also explains the sharp decline in the use of price undertakings after 2002. In 2004, ten EEC entered the European Union and its common customs union precluded any further trade defence proceedings.

However, there is likely to be a second trend that led to the decline of price undertakings, which is the surge of anti-dumping proceedings against China. Since 2002, anti-dumping proceedings against China have been very frequent and account for more than $30 \%$ of all EU anti-dumping proceedings. It is striking, however, that price undertakings vis-à-vis Chinese exporters are used very rarely and are employed in only $9 \%$ of proceedings (Table 2 ). Such a low rate cannot be explained only by the fact that the EU does not grant the market economy status to China. Certainly, this is responsible for the frequency of anti-dumping findings against China, as for nonmarket economies the constructed normal value will be based on costs and prices from outside the exporting country and thus are likely to be higher. This means that when the comparison is made between the normal value and the export price, the level of dumping is also likely to be higher. In the absence of market economy structures, the EU is presumably reluctant in accepting price undertakings. However, statistics shows that in other non-market economies, price undertakings have been used more often and account for nearly $30 \%$ of cases. Thus, there must be a different explanation for the comparatively low use of price undertakings vis-à-vis China.

\footnotetext{
${ }^{21}$ European Council Meeting on December 9 and 10, 1994, Presidency Conclusions, "The Commission, without prejudice to the position of the Council, in the exercise of its responsibilities for anti-dumping and safeguard measures and in the framework of the individual Europe Agreements, will offer information to any associated country before the initiation of proceedings and will give, on a case-by-case basis, where appropriate, a clear preference to price undertakings rather than duties in order to conclude anti-dumping cases where injury is found." (underline added).
} 
Table 2. Price Undertakings by Regions

\begin{tabular}{|c|c|c|c|c|c|c|c|c|c|c|c|c|}
\hline & \multicolumn{3}{|c|}{$1980 \sim 1989$} & \multicolumn{3}{|c|}{$1990 \sim 1994$} & \multicolumn{3}{|c|}{ 1994 2002 } & \multicolumn{3}{|c|}{ Since 2002} \\
\hline & $\begin{array}{c}\text { Measures } \\
\text { total }\end{array}$ & $\begin{array}{c}\text { of which } \\
\text { price } \\
\text { undertakings }\end{array}$ & $\%$ & $\begin{array}{c}\text { Measures } \\
\text { total }\end{array}$ & $\begin{array}{c}\text { of which } \\
\text { price } \\
\text { undertakings }\end{array}$ & $\%$ & $\begin{array}{c}\text { Measures } \\
\text { total }\end{array}$ & $\begin{array}{c}\text { of which } \\
\text { price } \\
\text { undertakings }\end{array}$ & $\%$ & $\begin{array}{c}\text { Measures } \\
\text { total }\end{array}$ & $\begin{array}{c}\text { of which } \\
\text { price } \\
\text { undertakings }\end{array}$ & $\%$ \\
\hline $\begin{array}{l}\text { Non-market } \\
\text { economies }\end{array}$ & 132 & 110 & $83 \%$ & 34 & 2 & $6 \%$ & 51 & 11 & $22 \%$ & 14 & 4 & $29 \%$ \\
\hline $\begin{array}{l}\text { Developing } \\
\text { countries }\end{array}$ & 67 & 29 & $43 \%$ & 39 & 11 & $28 \%$ & 94 & 27 & $29 \%$ & 35 & 7 & $20 \%$ \\
\hline $\begin{array}{l}\text { Developed } \\
\text { countries }\end{array}$ & 83 & 45 & $54 \%$ & 24 & 4 & $17 \%$ & 25 & 4 & $16 \%$ & 38 & 25 & $66 \%$ \\
\hline $\begin{array}{l}\text { Eastern } \\
\text { European } \\
\text { countries }\end{array}$ & 75 & 71 & $95 \%$ & 12 & 9 & $75 \%$ & 33 & 29 & $88 \%$ & 26 & 9 & $35 \%$ \\
\hline China & & & & & & & & & & 56 & 5 & $9 \%$ \\
\hline Sum & 357 & 255 & $71 \%$ & 109 & 26 & $24 \%$ & 203 & 71 & $35 \%$ & 169 & 50 & $30 \%$ \\
\hline
\end{tabular}

(Source) Own calculations based on Statistical Reports from European Commission

\section{B. Administrative Effectiveness of Price Undertakings}

The case-law analysis shows that the predominant category of rejections of price undertakings is rejections due to a lack of effective monitoring and the risk of circumvention. On a number of occasions, the Commission preferred the imposition of anti-dumping duties over price undertakings, as they were deemed more practicable in terms of enforcement and monitoring. ${ }^{22}$ The Commission has rejected price undertakings because it would not allow adequate monitoring of compliance with the terms of the undertaking. For example, the risk of compensatory pricing of the imported product under the inward processing regime could not be excluded. ${ }^{23}$

With regard to China, one explanation for rejection is the lack of effective monitoring that may occur when offering an undertaking is not able to provide sufficient guarantee of enforcing the undertaking. ${ }^{24}$ This can be particularly relevant when the support of the exporting country in controlling the undertaking is necessary; where the price

\footnotetext{
${ }^{22}$ For a comprehensive evaluation see Van Bael and Bellis (2011), p. 424.

${ }^{23}$ Potassium chloride (Belarus, Russia, Ukraine), 2000, OJ L 112/4, at para. 127.

${ }^{24}$ Certain prepared or preserved citrus fruits (China), 2008, OJ L 350/35, para 72; Certain tube or pipe fittings of iron or steel (China, Croatia, Thailand), 1996 OJ L 84/1, para. 45; Seamless pipes and tubes of iron or non-alloy steel (Hungary, Poland, Russia, Czech Republic, Romania, Slovak Republic, Croatia, 1997, OJ L 322/1, para. 87; Ammonium nitrate (Russia), 1995 OJ L 198/1, para. 98; Potassium chloride (Russia, Belarus, Ukraine) 2000 OJ L 112/4, para. 128.
} 
undertaking contains a quantitative element; minimum prices up to a certain volume threshold and a duty for the remainder of the imports that needs to be controlled by the authorities of the exporting country. ${ }^{25}$ This is supported by the empirical findings of Tharakan (1991), who finds that the probability of undertakings being accepted is low in cases in which a number of exporters are involved. The greater the number of exporters, the higher the administrative burden to ensure compliance at the satisfactional level.

Also with respect to China, a particular risk of circumvention has been identified in which the company is an integrated producer of the category of products. The broad array of production including the product concerned opens a wide range of marketing options to the company that may render the undertaking impossible to set up and monitor. ${ }^{26}$ In this case, cross-compensation can allow the company to compensate for losses in the product concerned through higher prices in the related products of the same product category. ${ }^{27}$

The risk of cross-compensation was also at stake in the case of Chinese Monosodium Glutamate (MSG). In this case, the Commission found that MSG prices were negotiated globally with large international customers having production facilities inside and outside the Union. The Commission thus considered that the risk of the crosscompensation of prices between sales agreements made with international customers located outside the Community was high and that it would be extremely difficult to detect this risk in the framework of the undertaking. ${ }^{28}$

\section{Removal of Dumping and Injurious Effect}

Besides the above procedural grounds, the EU Commission rejected price undertakings for substantive reasons related to the effective elimination of the injurious effects of the dumping practice. In some cases, the Commission simply stated that

\footnotetext{
${ }^{25}$ Ammonium nitrate (Russia), 2008 OJ L 185/1; Certain seamless pipes and tubes of iron or non-alloy steel (Croatia, Ukraine), 2000 OJ L 45/1.

${ }^{26}$ Van Bael and Bellis (2011), p. 425; see, e.g., Certain candles, tapers and the like (China), 2009 OJ L 119/1 para. 147; Certain iron or steel fasteners (China), 2009 OJ L 29/1, para 220; Certain welded tubes (Belarus, China, Thailand, Ukraine, Russia), 2008 OJ L 343/1, para. 346

${ }^{27}$ Solutions of urea and ammonium nitrate (Belarus, Algeria, Russia, Ukraine, Lithuania), 2000 OJ L 238/15, para. 48; Urea (Belarus, Bulgaria, Croatia, Estonia, Libya, Lithuania, Romania, Ukraine, Egypt, Poland), 2002 OJ L 17/1, para. 143; in Urea (Lithuania), 2002 OJ L 168/51, the Commission ultimately accepted a price undertaking because the risk of cross-compensation was reduced by extending coverage of the undertaking from urea to other fertilizers exported to the Community..

${ }^{28}$ Monosodium glutamate (China), 2008 OJ L 332/1, para 67.
} 
the price undertaking would not be as effective as ad valorem duties in adequately removing the injury caused to Union industry.

Most relevant is the rejection of undertakings due to the high volatility of prices, because in such circumstances the price fluctuations combined with a rigid minimum price undermine the remedial effect of the measure. Accordingly, the Commission referred to the short-term volatility of prices on previous occasions in order to reject a price undertaking. ${ }^{30}$ This is because high volatility can jeopardize the effectiveness of price undertaking, leaving ad valorem duties the most effective instrument.

Similarly, the Commission has also frequently refused to accept price undertakings due to volatile raw material prices. ${ }^{31}$ Generally, when prices for raw materials are volatile, one could adjust the price undertaking by using an index, according to which the undertaking is adjusted to reflect fluctuations in raw material prices. However, indexing does not work when no stable relationship exists between the price of the product concerned and the price of individual raw materials. In circumstances in which the price fluctuations of the product concerned could not be linked to individual raw materials, the Council has refrained from indexing the price of the production concerned to certain raw materials. ${ }^{32}$ For instance, in Dihydromyrcenol from India, the Council considered the possibility of indexing the minimum import price to the main raw material. However, the Council found that fluctuation in the price of the product concerned could not be sufficiently explained by fluctuation in the main raw material. ${ }^{33}$ Thus, in cases in which there is no significant correlation between the main raw materials and the price of the product concerned, it is difficult to establish a close correlation between the product's price volatility and the volatility of the main raw materials prices.

This effect would be further aggravated in instances in which there is a strong increase of prices after the investigation period. An undertaking based on the price level

\footnotetext{
${ }^{29}$ Ammonium nitrate (Poland, Ukraine) 2000 OJ L 187/12, para 58: Silicon carbide (Ukraine), 1997 OJ L 254/6, para 22; Ammonium nitrate (Russia), 1995 OJ L 198/1, para. 99.

${ }^{30}$ Certain iron or steel fasteners (China), 2009 OJ L 29/1; Certain prepared and preserved citrus fruits (China), 2009 OJ L 350/35, para. 72; Ferro-silicon (China, Egypt, Kazakhstan, Russia, Macedonia), 2008 OJ 55/6, para 131; Council Regulation (EC) No 1679/2002 of 23 September 2002, at para. 77.

${ }^{31}$ Council Regulation (EC) No 211/2008 of March 10, 2008, at para. 69; Council Regulation (EC) No 63/2008 of January 21, 2008; Council Regulation (EC) No 1679/2002 of 23 September 2002, at para. 77.

32 Council Regulation (EC) No 260/2007 of March 9, 2007 imposing a definitive anti-dumping duty on imports of tungsten electrodes originating in China, at para. 59; Council Regulation (EC) No 63/2008 of January 21, 2008 imposing a definitive antidumping duty on imports of dihydeomyrcenol originating in India, at para. 36.

${ }^{33}$ Council Regulation (EC) No 63/2008 of January 21, 2008 imposing a definitive anti-dumping duty on imports of dihydeomyrcenol originating in India, at para. 36 .
} 
observed during the investigation period would be, from its very beginning, deprived of any remedial effect in this case. Even if such an undertaking had a remedial effect upon its initiation, this remedial effect would quickly deteriorate or become obsolete. Moreover, given the lack of significant correlation between the prices of individual raw materials and the price for the product concerned, it would be impracticable to correct this defect by indexing the target price of the product concerned. In sum, in cases of rapidly increasing and highly volatile raw material prices, the Commission would be unable to restore a continuous non-injurious and competitive price level.

On other occasions, the Commission has rejected price undertakings offered by importers. As mentioned above, importers often pursue interest contrary to the Community industry, as they generally care about cheap import prices. The Commission's approach towards price undertaking offered by importers is characterized by circumvention concerns and injury considerations. ${ }^{34}$ The Commission has stated that it does not usually accept undertakings offered by importers, although the ECJ found that the Basic Anti-Dumping Regulation does not rule out the possibility of the Commission accepting an undertaking offered by an importer in exceptional cases. However, it remains unclear from the case-law what these exceptions may be. The Court found that importers tend to offer price undertakings that allow them to continue to import products at dumped prices. Moreover, compliance and monitoring issues arise, since other importers of the product would have to receive the same treatment and the involvement of a large number of companies would further complicate effective implementation. ${ }^{35}$ This explains the reluctance of the Commission to accept price undertakings offered by importers by arguing that any measure specific to a particular category of importers would be complex and open to circumvention. ${ }^{36}$

\section{Ad Valorem Duties}

In light of the above, price undertakings lead to various risks for the effective enforcement of anti-dumping measures. Indeed, the Commission's reluctance in adopting minimum price duties is a logical consequence of its own finding that the

\footnotetext{
${ }^{34}$ Van Bael and Bellis (2011), p. 426.

${ }^{35}$ Joined Cases 133/87 and 150/87, Nashua Corp. v. Commission and Council, 1990 ECR I-719.

${ }^{36}$ Certain footwear with uppers of leather (China, Vietnam), 2006 OJ L 275 1, para. 316; Plain paper photocopiers (Japan), 1987 OJ L 5412.
} 
imposition of a variable duty results in inherent problems of enforcement. ${ }^{37}$ Therefore, the Commission generally exercises its discretion in choosing the kind of duty based on enforcement considerations, linked to the effective enforcement of measures and the ease of administration. The imposition of ad valorem anti-dumping duties is the most established decisional practice. They have proven to be the most reliable and easiest to administer measures. They normally guarantee the effectiveness of anti-dumping measures, as they are difficult to circumvent. Therefore, in the vast majority of cases anti-dumping measures have been adopted in the form of $a d$ valorem duties, ${ }^{38}$ to an extent that their use has recently become the rule in anti-dumping proceedings in which measures are imposed. In turn, the Commission has adopted minimum price duties only in cases in which other factors mitigated circumvention risk.

\section{Anti-competitive Nature of Price Undertakings}

A further major obstacle for price undertakings is possible conflict with competition goals, because a price undertaking of one exporter tends to become a fixed minimum price. Interestingly, in the EU case law, there are only a few occasions in which the Commission rejected price undertakings on the basis of anti-competitive effects. ${ }^{39}$ On other occasions, the Commission rejected price undertakings without reference to the evidence of potential anti-competitive effects, although the situation was very similar. Against this background, this section examines the market environments in which price undertakings may cause anti-competitive effects.

\footnotetext{
${ }^{37}$ Council Regulation (EC) No 1905/2003 of October 27, 2003 imposing a definitive anti-dumping duty and collecting definitively the provisional duty imposed on imports of furfuryl alcohol originating in the People's Republic of China, para. 52.

${ }^{38}$ Case C-49/88, Al-Jubail Fertilizer Company (Samad) et Saudi Arabian Fertilizer Company (Safco) v Council, [1991] ECR, I-3187, 24 ("the ad valorem duty is by far the most common type of duty in cases of dumping"). See, e.g., Council Regulation (EC) No 398/2004 of March 2, 2004 imposing a definitive anti-dumping duty on imports of silicon originating in the People's Republic of China; Council Regulation (EC) No 492/2004 of March 8, 2004 amending Regulation (EC) No 1339/2002 imposing a definitive antidumping duty on imports of sulphanilic acid originating, inter alia, in India; Council Regulation (EC) No 648/96 of March 28, 1996 imposing a definitive anti-dumping duty on imports of bicycles originating in Indonesia, Malaysia, and Thailand.

${ }^{39}$ Council Regulation No 1965/98 of September 9, 1998, at para. 56; Council Regulation No 2322/85 of August 12, 1985, at para. 22; Council Regulation No 221/2008 of 10 March 2008, at para. 70.

${ }^{40}$ Monosodium glutamate (China), 2008 OJ L 332/1; Barium Chloride from China and GDR, OJ 1983 L110/11; Isopropylidenediphenol from USA, OJ 83 L 199/4; Photocopiers from Japan, OJ 1987 L 54/12.
} 


\section{A. Conflict between Anti-dumping Rules with Competition Goals}

By its nature, a price undertaking consists of a written statement filed with the Commission by an exporting producer willing to increase the prices of its exports to the Community. ${ }^{41}$ Formally, this is not a problem from a competition law perspective, as price undertakings are not agreements between competitors but individual commitments given to the Commission by each of the exporters willing to increase the prices of its exports to the Community. As such, they do not fall within the terms of Article 101 of the Treaty of the Functioning of the European Union, which prohibits cartels and other agreements that could disrupt free competition. Thus, no antitrust case has arisen concerning the negotiation of a price undertaking.

In substance, however, price undertakings lie at the intersection between antidumping and antitrust, because anti-dumping rules allow practices that may be incompatible with competition considerations. From an economic viewpoint, the two policies pursue different objectives that eventually may lead to conflicting situations. Anti-dumping is a trade remedy for industries injured by import competition. The final goal of antitrust, on the other hand, is to promote consumer welfare and production efficiency, which in part depend upon market contestability, wherein import competition often plays a key role. ${ }^{42}$ These conflicts are most evident when anti-dumping policies allow practices that are explicitly forbidden by competition law such as an agreement on minimum prices and quantitative trade restrictions.

Thus, the conflict between anti-dumping and competition policies is not confined to price undertakings but generally inherent to their opposite policy targets. Dumping practices generally increase consumer welfare to the detriment of the rents of national producers.

From a welfare perspective, a price undertaking equivalent to a given level of duty will imply a lower level of total welfare for the EU given the loss of tariff revenue. ${ }^{43}$ This result holds under very general demand and cost conditions and under Cournot and under Bertand competition. It is also independent of the timing of the firms' decisions.

Concerning the distributional effect, although in static terms duties and undertakings may be have equivalent effects on domestic producers and consumers, price undertakings may disadvantage European producers through quality reversals, as

\footnotetext{
${ }^{41}$ Van Bael and Bellis (2011), p. 433.

${ }^{42}$ José Tavares de Araujo (2001, p. 7).

${ }^{43}$ Pauwels and Springael (2002).
} 
shown by Vandenbussche and Wauthy (2001). Another important issue is whether exporters absorb part of the duty by lowering their received export price. In this case, depending on the levels involved, it could be the case that anti-dumping duties result in lower prices for consumers than price undertakings and thus smaller anti-competitive effects. However, this has an important caveat. The EU anti-dumping law includes an anti-absorption provision, and therefore, exporters that do this may be subject to higher future duties as punishment for this behavior.

\section{B. Treatment of Anti-competitive Effects in the EU's Practice}

Article $3(\mathrm{~g})$ of the EU Treaty establishes that the Community establish " $a$ system ensuring that competition on the internal market is not distorted." The Basic AntiDumping Regulation requires that "restrictive trade practices of, and competition between, third country and Community producers" be taken into account in the assessment of injury. Regulation thus emphasizes the need to take into account possible anti-competitive effects resulting from the adoption of measures.

On this basis, the Commission has avoided applying a minimum price duty, in circumstances in which there was only a small number of players because a minimum price would reduce price competition. In such cases, the Council rejected price undertakings in consideration of the anti-competitive effects the price undertaking would generate. ${ }^{45}$

In Glycine, the Commission rejected the undertakings offered by the two exporters under investigation because "[in] a market where only a limited number of companies are competing with each other, an alignment of prices resulting from undertakings of the kind offered by the Japanese companies, i.e. to respect the same minimum price, would reduce competition. "46 As the Commission pointed out, the anti-competitive effect would be less likely to occur as a result of the imposition of anti-dumping duties, because existing differences in the prices charged in different transactions by the two companies could continue. Apparently, the Commission's decision was based on the fact that there was only one EU producer and two foreign exporters present in the

\footnotetext{
${ }^{44}$ Vermulst and Ikenson (2007)

${ }^{45}$ Council Regulation No 1965/98 of 9 September 1998, para. 56; Council Regulation No 2322/85 of 12 August 1985, para. 22; Council Regulation No 221/2008 of March 10, 200, at para. 70.

${ }^{46}$ Glycine (Japan), 1985 OJ L 218/1.
} 
glycine market. This would make it easy for participants to abuse price undertakings for illegal price fixing. ${ }^{47}$

On another occasion, in the case of Polysulphide Polymers, the Commission considered a price undertaking inappropriate as well in light of the duopolistic supply structure of the Community market. The Commission found "that given the duopolistic supply structure of the Community market, price undertakings are not appropriate." The Glycine and the Polysulphide Polymers cases remain some of the few cases in which considerations of competition policy have significantly affected the outcome of an anti-dumping proceeding. ${ }^{49}$ It has been submitted that the Commission pursues a long established policy which tends to favour the interests of Community industry over those of consumers.

\section{Market Structures and Anti-competitive Effects}

Under certain market conditions, undertakings will have the effect of fixing a minimum price which is more or less the same for all exporters found to have sold their products at a dumped price. Moreover, depending on market conditions, a price undertaking can also become transparent to national competitors and thus become a minimum price for the entire market. In this respect, price undertakings constitute a striking contrast to the objectives pursued by antitrust law, which tends to stimulate price competition in order to provide consumers with the lowest possible price. In these cases, the Commission is acting as an intermediary through which foreign exporters and Community producers harmonize their price levels.

Particularly in market settings in which the market is dominated by only few large competitors, the minimum price offered for purposes of the undertaking may become a reference price in the transparent way. This transparency would be increased in cases in which the Commission uses an "analogue country" in order to determine the "normal value" of the product concerned; competitors of the exporter offering an undertaking

\footnotetext{
${ }^{47}$ Perone (1995), p. 42.

${ }^{48}$ Council Regulation No $1965 / 98$ of 9 September 1998, at para. 56

${ }^{49}$ Sodium Carbonate (Soviet Union), OJ 1979 L 297/12; Synthetic Fibres of Polyester (Yugoslavia, GDR, Romania, Turkey), OJ 1987 L 103/38.

${ }^{50}$ Van Bael and Bellis (2011), p. 434; Stegemann (1990), p. 268; Perone (1995), 40.

${ }^{51}$ An "analogue country" is chosen when the exporter's country is considered to be a non-market economy.
} 
would be able to compute the proposed minimum price by taking into account the production costs in the analogue country and the "normal" profit margin of 5\%, which the Commission often suggests in its injury calculation. As a result, the competitors of the exporter can calculate, with presumably only a small margin of error, the undertaking price that the exporting company offered.

Even if the competitors could not calculate the undertaking price, it is typical for narrow markets that the actual undertaking price becomes known shortly after it becomes applicable. Price negotiations are conducted in such a way that buyers indicate what level of price concessions are needed in order for one seller to make an offer that is better than that of the seller bound by the undertaking.

In sum, in a context of a duopolistic or oligopolistic market structure accepting a minimum price undertaking will entail great risk for effective competition. The high degree of transparency among the market operators exacerbate the negative competitive effects. In contrast, an ad-valorem duty that is effectively remedying dumping tends to increase competition.

However, the anti-competitive nature of price undertakings vis-à-vis duties should not be generalized. In a static perspective, both price undertakings and duties can be equivalent provided their levels are fixed as such. In this case, anti-dumping duties can also effectively impose a minimum price in the market. The crucial issue is the dynamic evolvements of prices. If prices tend to increase, then duties will have a greater anti-competitive effect, given that the price undertakings may ultimately not bind. On the other hand, if market prices decrease, then the price undertakings would be more restrictive than a duty.

\section{Conclusions}

For a long time, the EU Commission has considered price undertakings as a suitable alternative to traditional ad valorem-duties. Until 2001, almost every other antidumping proceeding was settled by way of implementing a minimum price. In recent years, however, acceptance of price undertakings has decreased sharply and in the last four years, price undertakings were implemented only less than ten per cent of antidumping proceedings.

An examination of the reasons for the declining relevance of price undertakings 
reveals that there is generally no legal constraint upon the Commission to dismiss offers of price undertakings. Indeed, both EU and WTO rules leave the Commission wide discretion on whether it considers price undertakings a suitable alternative to antidumping duties.

However, within this broad scope of discretion the EU Commission has developed a decisional practice that clearly underscores the practical and substantive advantages of ad valorem-duties over minimum prices.

One major reason for the declining relevance of price undertakings is the accession of EEC to the EU. Price undertakings were the preferred instrument to conclude antidumping proceedings between the EU and EEC prior to their accession. From 2002, with China becoming a subject of anti-dumping measures more frequently, price undertakings were used less often than before. The case-law indicates that monitoring and circumvention issues are often referred to as grounds to reject price undertakings offered by Chinese exporters.

There are reasons in relation to the effective monitoring of price undertakings and limiting the risk of circumvention. Price undertakings are often difficult to monitor and can be circumvented. Anti-dumping measures, by contrast, have proven to be the most reliable to administer measures. They normally guarantee the effectiveness of antidumping measures, as they are difficult to circumvent and require less effort to monitor. Second, there are reasons related to the suitability of price undertakings to effectively remove the dumping practice and the injurious effects thereof. Price undertakings may be particularly inappropriate in the context of high price volatility, because in such circumstances the price fluctuations combined with a rigid minimum price undermine the remedial effect of the measure.

A further ground for rejecting price undertakings is their potential anti-competitive effects. Indeed, as price undertakings implement minimum prices they tend to exacerbate the conflicting aspect of anti-dumping and competition policies. The more transparent the market structures and the lower the number of significant competitors in the market, the higher is the risk that price undertakings will become a minimum price for all companies in the market.

On balance, the decline in price undertakings as a way to settle anti-dumping procedures can be explained by the comparative advantages of ad valorem-duties visà-vis price undertakings. Procedurally, they are easier to monitor and more difficult to circumvent. In fact, they adequately remove dumping and its injurious effect on industry. Anti-dumping duties can also minimize potential conflicts with competition. 
Thus, due to these reasons the scope of price undertakings is likely to remain rather limited in the future anti-dumping settlement.

Received 30 August 2013, Revised 11 October 2013, Accepted 15 December 2013

\section{References}

Belderbos, R., H. Vandenbussche and R. Veugelers (2004). Antidumping duties, undertakings, and foreign direct investment in the EU. European Economic Review 48. 429-453.

Davis, Lucy (2009). Ten years of anti-dumping in the EU: economic and political targeting. ECIPE Working Paper 02/2009.

European Commission (1998), Seventeenth Annual Report from the Commission to the European Parliament on the Community's Anti-dumping and Anti-subsidy Activities.

Everaert, Greetje (2003), Technology Adoption under Price Undertakings, Discussion Paper 137/2003 Katholieke Universiteit Leuven, LICOS Centre for Transition Economics,

Mendes, M. (1991), Antitrust in a World of Interrelated Economies. The Interplay Between Antitrust and Trade Policies in the U.S. and the E.E.C, Bruxelles: Editions de l'Universite de Bruxelles.

Messerlin, Patrick (1989), The EC Antidumping Regulations:A First Economic Appraisal, 1980-1985, Weltwirtschaftliches Archiv 125, pp. 563-87.

Moore, Michael O. (2005), VERs and Price Undertakings under the WTO. Review of International Economics, Vol. 13, No. 2, pp. 298-310.

Pauwels/Springael, AEJ June 2002, Vol. 30, No.2, 121-135.

Perone, Francesco (1995), Settlement of Anti-Dumping Cases by Price Undertaking: The European Community and United States Practice Institute of Comparative Law, McGill University, August 1995.

Prusa, Thomas and Skeath, Susan (2002). Modern commercial policy: Managed trade or retaliation? Choi, E. K. and J. Hartigan (eds.). Handbook of International Trade. Vol. II. Malden: Blackwell Publishing.

Rovegno, L. / Vandenbussche, H., A comparative analysis of EU Antidumping rules and application, Discussion Paper 2011, Nr. 23.

Stegemann,K. (1990), EC Anti-Dumping Policy: Are Price Undertakings a Legal Substitute for Legal Price Fixing, Review of World Economics 126, pp. 268-98.

Tavares de Araujo, José (2001), Legal and economic interfaces between antidumping and competition policy, Division of International Trade and Integration, United Nations, Santiago, Chile, December.

Tharakan, P. K. M. (1991). The political economy of anti-dumping undertakings in the European Communities. European Economic Review 35. 1341-1459.

Van Bael and Bellis (2011), EC Anti-Dumping an Other Trade Defence Instruments, 5th edn., Alphen aan den Rijn, Kluwer Law International. 
Vandenbussche, World Competition. Law and Economic Review, 1995, 55-74.

Vandenbussche, Hylke / Wauthy, Xavier (2001), Inflicting injury through product quality: how European antidumping policy disadvantages European producers, European Journal of Political Economy, Vol. 17.2001, 1, p. 101-116.

Vermulst, Edwin and Daniel Ikenson (2007) Zeroing Under the WTO Anti-Dumping Agreement: Where Do We Stand?, Issue 6, pp. 231-242.

Zanardi, Maurizio (2004), Anti-dumping: What are the Numbers to Discuss at Doha?, The World Economy, Wiley Blackwell, vol. 27(3), pages 403-433. 